\title{
Relationship between Innovation Management and Innovative Organizational Culture in Logistics Companies: A Study in the City of Mersin*
}

\author{
Bekir Çağlar Bayhan1, Oya Korkmaz² 우
}

\begin{abstract}
Innovation management is essential for the growth and success of an organization. Innovation management is a precursor to the establishment of an innovative organizational culture. By encouraging staff to engage in innovative behavior, innovation management facilitates the creation and establishment of a culture of innovation in an organization. An organization can only change its cultural attitude and behavior by investing in innovation management practices-i.e., by applying innovation to the organization's strategies, systems, and procedures. To effectively establish an innovative culture, organizations should continuously implement innovation management practices. Only in this way can innovation become an organization's dominant culture. Because innovation management practices increase the commitment to innovation, they facilitate the formation and development of an innovative organizational culture and eventually become the fundamental values of the organization. In this study, we posited that innovation management constitutes the basis for the formation of an innovative organizational culture and analyzed this hypothesized relationship. For this purpose, we collected data using the face-to-face survey method with 200 white-collar staff members working in logistics companies that operate in Mersin, Turkey and that apply innovative management practices. We assessed the collected data using SPSS 20.0 (Statistical Package for Social Sciences) and AMOS 24.0 (Analysis of Moment Structures) programs. Our analysis showed a highly significant positive relationship between innovation management and innovative organizational culture.
\end{abstract}

\section{Keywords}

Innovation Management, Innovative Organizational Culture, Logistics

\section{Introduction}

Innovation management is one of the tools organizations use to survive in today's highly competitive business world. Successful innovation management practices can eventually become a part of an organizational culture. In short, in order for organizations to adapt to changing environmental conditions and succeed, they need to behave in innovative ways that align with the changes in the environment and effectively manage the situations they face. In a dynamic environment, innovation can be a handy and effective management tool

* This study is derived from the master thesis titled "The Relationship between Innovation Management and Innovative Organizational Culture in Logistics Companies" which was accepted by Mersin University Institute of Social Sciences in 2018.

1 Bekir Çağlar Bayhan, Koluman Otomotiv Endüstri A.Ş., Tarsus, Turkey. E-mail: bcbayhan@hotmail.com

2 Corresponding Author: Oya Korkmaz (Assoc. Prof. Dr.), Tarsus University, Faculty of Applied Sciences, International Trade and Logistics Department, Mersin, Turkey. E-mail: oyakorkmaz67@tarsus.edu.tr Orcid: 0000-0003-4570-803X

To cite this article: Bayhan, B. C., \& Korkmaz, O. (2021). Relationship between Innovation Management and Innovative Organizational Culture in Logistics Companies: A Study in the City of Mersin. Istanbul Business Research. Advance online publication.

http://doi.org/10.26650/ibr.2020.50.0058 
for managers. Positive organizational cultures that support innovative products and services eliminate organizational weaknesses and enable organizations to react positively to changing market conditions.

Innovation management is a useful tool for improving the abilities of organizations. However, this useful tool needs to be managed effectively. When a new innovation approach is adopted within the scope of innovation management, it must be ensured that the employees be brought together and that the new approach be adopted by them for the internal adaptation process of this approach to be completed successfully. In addition, to successfully implement innovation management and ensure that innovations are integrated into organizational cultures, managers must encourage their employees to support innovation and demonstrate a strong vision in this respect. Thus, organizations that turn into innovative companies create business environments that promote innovative cultures, and the cultivation of such innovative cultures within organizations maximizes the professional skills of the organizations' employees.

Because innovations yield results by means of innovation management and because companies benefit from these innovation activities at the highest levels, companies must adopt innovation management as an essential corporate strategy. To sustain cultures of innovation, it is necessary to make high-impact innovations and destroy existing organizational bureaucracies. Thus, every fundamental innovation and change will contribute to the formation of strong and creative organizational cultures. The innovative organizational culture thus formed will provide the organization with the means of good strategic management in terms of creating and implementing advanced ideas. Innovation management and innovative organizational cultures also play important roles in shaping organizations' human resource structures.

We conducted this study to demonstrate that innovation management practices, which inevitably result from changes in environmental conditions, shape organizational cultures after a certain period of time; we therefore analyzed the relationship between innovation management and innovative organizational culture. The findings of our analyses indicate that organizations should cultivate organizational cultures that are open to research that leads to innovation because organizational cultures are great platforms for innovation and change.

\section{Innovation Management}

Joseph Schumpeter (1930) is an acclaimed Austrian political economist whose study of "creative destruction" within industries helped lay the foundations for innovation management as a practice (Hörlesberger et al., 2007: 211). And then Tidd and Bodley (2002) described innovation management as a process of designing new ideas and widespread implementation of such ideas by the organization (Yi and Xiangyun, 2013: 24). Innovation management provides implementers with numerous approaches and frameworks to implement innovation in the best manner (Hirte and Roth, 2018: 115). 
The effective management of innovation is a requirement for an organization to maintain its current status, attract desirable customers and attain competitive advantage over other players in the market (Haleem et al., 2018: 19). In an organization where innovation management is applied, managers mentor their employees and do not dictate their orders to them (Kalivas et al., 2013: 21).

Innovation management plays an essential role in the management of companies that face uncertainties as a result of increasing globalization and rapid changes in technology and the rapid integration of these changes into the business world (Chong and Chun-sheng, 2007: 2005). Innovation management requires systematic innovation at all organizational levels. The mission of innovation management is to channel innovation into organization. Knowing what happens in the course of innovation management gives us a variety of new ways to understand organizational reality. For these reasons, organizations must assess and understand innovation management (Morente and Ferràs, 2017: 642-645).

In order to ensure effective participation in innovation efforts, the management models that provide guidance in defining organizational processes to benefit from innovation opportunities throughout the organization are required to be adopted in that organization (Bagno et al., 2017: 637). Because the growth and performance of an organization depends on the effective management of innovation in a competitive climate (Taghizadeh et al., 2017: 130).

Innovation management consists of four dimensions: strategy, system, culture and ecosystem. While the strategy dimension includes the criteria of innovation management and the effects of intellectual property risk, the system dimension encompasses the management of thought and information among different innovation processes. Moreover, while the culture dimension is characterized by education, training and employee participation, the ecosystem dimension involves collaboration with partners, intellectual property management and the analysis of new technologies. These four dimensions certainly impact innovation processes (Hirte and Roth, 2018: 115). According to another common opinion, the sub-dimensions of innovation management include innovative leadership, innovation culture, innovation process and information management (Plessis and Pretorius, 2018: 1).

Many studies of innovation management have suggested that to mitigate the risks that innovation-oriented companies may face they must actively monitor, evaluate, analyze and seek to control future events (Etges and Cortimiglia, 2019: 364).

\section{Innovative Organizational Culture}

Groups in which people come together to attain specific goals and collaborate in systematic ways are called organizations (Ülgen and Mirze, 2014: 22). Organizational culture, meanwhile, is expressed via the beliefs and values within companies that motivate employ- 
ees and increase job productivity (Owoyemi and Ekwoaba, 2014: 169). In other words, an organizational culture is the standard set of behaviors and habits shared by the members of an organization. Organizational culture serves as social cement for the life of an organization. It also serves as powerful management tool in organizations that allow their members to act independently and consistently. Organizational culture is one of the important determinants of sustainable innovation and financial performance (Davies and Buisine, 2018: 103).

Culture plays an important role in the cultivation of innovative success. To change their cultures, organizations must ensure that they define and assimilate the components of the innovative culture. These components of innovative culture include: innovative mission and vision statements, democratic communication, safe spaces, flexibility, collaboration, boundary spanning, incentives and leadership (Dombrowski et al., 2007: 190).

Asmawi and Mohan (2011), on the other hand, expressed the cultural components that helped research and development as an eight-factor structure. Asmawi and Mohan (2011) have defined these factors respectively as teamwork and knowledge sharing, empowerment and recognition, conformity and impediments to R\&D, risk-taking, customer orientation, autonomy, social networking and organizational design. They also showed in their research that these dimensions can be used as a management tool to measure the basic culture of research and development type organizations. They stated that R\&D managers can benefit from these eight factors while forming the basis of the research culture in their units and this will also provide a basis for management to take the initiative to manage $\mathrm{R} \& \mathrm{D}$ activities. They also showed that these factors can be used as benchmarking parameters in comparing various aspects of organizational culture of research and development companies with enterprises that are leaders in the industry (Asmawi and Mohan, 2011: 509).

Innovative culture is a special form of regulation that makes innovation a natural process in the organization and promotes innovation for employees at all levels. Innovative culture has its own characteristics. These characteristics include: the presence of innovative leaders, managers, teams and individuals; the proper organizational conditions for innovation; and the establishment of multiple and easy connections outside the organization for innovation. All of these characteristics are based on innovative and exploratory capabilities (observing, questioning, networking, experimenting and partnership). To create an innovative organizational culture in an organization, these capabilities must be extended to the whole organization (Davies and Buisine, 2018: 103). At the same time, in order to create an innovative organizational culture in an organization, six kinds of attitudes must be fulfilled. These attitudes include the ability of managers to take risks, encouraging creativity, the participation of all employees to create an innovative culture, holding both managers and their employees accountable for their behaviors, allowing employees to develop themselves based on their areas of interest, and using employees' unique talents to more effectively fulfill the company's mission (Szczepańska-Woszczyna, 2014: 31). 
Maher (2014) has set forth seven important differences of highly innovative organizations as follows. Organizations and leaders use these seven characteristics to strengthen and assess the culture of innovation in their organizations. The seven important differences set forth by Maher (2014) for highly innovative organizations are as follows:

- employees should express their ideas without fear that such ideas may have negative consequences and should think that they can try out new ideas;

- leaders of innovative organizations should be more interested in learning by learning from mistakes than punishing negative consequences;

- top management should provide the financial resources employees require to carry out innovation processes and demonstrate positive attitudes towards innovation;

- because information is a crucial resource for innovation, the organization should create an environment that facilitates the extensive and systematic gathering of information inside and outside the organization, and that make said information easily and quickly accessible and clearly communicated;

- the leader should clearly indicate that innovation is a desired goal of the organization and create a motivated team to implement the organization's vision;

- innovation should be supported by symbols and rituals that define and promote it; and

- in organizations with high innovation based efficiency, innovation is actually the product of the managers' logic of using a practical management tool. Leaders must consider how to identify and put into practice the potential and capabilities of employees who understand creative thinking, management and management methods. Leaders must also cultivate a collaborative business environment to fuel innovation in their organizations. In short, different ways of thinking and different perspectives and diversity will provide leaders with a solid foundation for innovation (Szczepańska-Woszczyna, 2014: 31-32).

\section{Research Methodology}

\section{Purpose and Importance of the Research}

In this study, we examined the relationship between innovation management and innovative organizational culture in the logistics sector. Additionally, we set out to show the decision makers of logistics companies that innovation management can improve their companies' 
positions in the market, give them competitive advantages, and enhance their corporate images. In summary, we conducted this study to demonstrate that logistics companies can make innovation the defining characteristic of their organizational cultures by implementing innovation management.

\section{Population and Sample of the Research}

Today, the logistics sector has a very important place in the functioning of the global economy. In international trade, product movement takes place through logistics processes. Because of this feature, the logistics sector has connection with every field in the global economy. Thanks to these connections, every innovation or change in business affects the logistics industry. For this reason, innovation is experienced intensely in the logistics sector. Due to this feature of the sector, the logistics sector was preferred in this study.

The population of the research is the logistics companies operating in Mersin and the sample consists of the logistics companies that operate in Mersin and have implemented innovation management. The reason for choosing these logistics companies is the absence of such a study on this sample relating to the subject until today and that the region is one of the most important logistics centers of Turkey. Mersin is a complete logistics center with land, sea and air transportation. It ranks first as the largest container port of Turkey (MIP, 2018). It is also one of Turkey's most important logistics centers as a bridge between the Middle East and European markets. For this reason, many of the logistics companies operating in Mersin have gained corporate identity and are the most important logistics providers known worldwide. International and domestic competition of these companies forced them to give importance to innovative actions and to implement innovation management in their companies.

For this reason in the sample selection of our study, the factors such as companies' being corporate and open to innovations, their adoption of innovative management as their principle, managers' continuously doing research for innovation, usage of the most advanced system software in areas such as inventory management, accounting and operations, giving importance to the usage of environmental friendly tools, loading/lifting equipment's complying with current technologies, giving importance to training of personnel regarding areas such as work safety, personal development and professional issues, dominating in the market and employing people who are experts in their fields, have been effective. As can be seen, the sample of the research consists of logistics providers who realize the importance of innovation management practices and apply them to their businesses. For this reason, in the study, large corporate companies that have managers who realize the importance of change and transformation and apply innovation management in their companies formed the sample of our research. For this reason, in this study, a purposeful sampling method being among non-probable sampling methods has been used. In the research, data were collected from 
200 white-collar personnel working in logistics companies operating in Mersin, which were registered with the International Transport and Logistics Service Providers Association (UTI$\mathrm{KAD}$ ) and which have implemented innovation management.

\section{Data Collection Method}

We obtained the data necessary to test our hypotheses using the face-to-face survey method with the sample group. The survey consisted of three sections: demographic data, an innovation management scale and an innovative organizational culture scale. It included 46 questions in total.

For the innovation management scale, we used the 26-item scale developed by Gürsel \& Sü Eröz (2017). This scale contains 5-point Likert-type items with the following possible responses: "1- Strongly disagree," "2- Disagree," "3- Neither agree nor disagree," "4- Agree," or "5- Strongly agree."

For the innovative organizational culture scale, we used 8 expressions that are listed in the Organizational Culture Index developed by Wallach (1983) and that help evaluate the innovative organizational culture. This scale contains 5-point Likert-type items with the following possible responses: "1- Strongly disagree," "2- Disagree," "3- No idea," "4- Agree," and "5- Strongly agree."

\section{Model and Hypotheses of the Research}

This study's dependent variable was innovative organizational culture and its independent variable was innovation management. The sub-dimensions of innovation management include innovation performance, innovation capability, innovative organizational structure, participation in innovation processes, innovation desire and innovation support.

We list the hypotheses generated to investigate the relationship between the dependent and independent variables and the relationship between demographic factors and the dependent variable below. In addition, Figure 1 shows the study's conceptual model related to these hypotheses. 


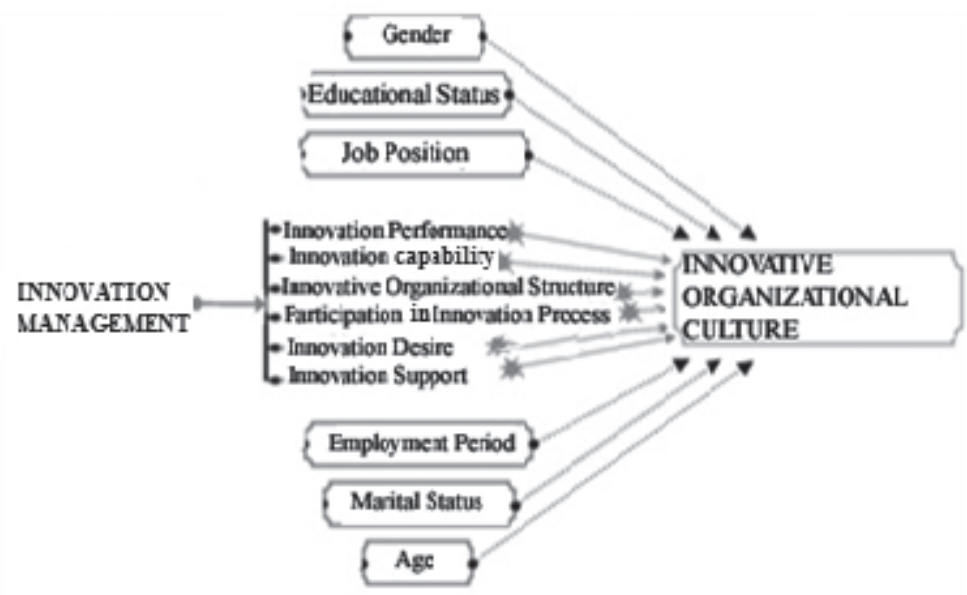

Figure 1. Research Model and Hypotheses

This conceptual model is based on Schumpeter's idea of creative destruction relating to entrepreneurship. These ideas, put forward by Schumpeter, formed the foundations of innovation management (Hörlesberger et al., 2007: 211). Later, by making use of Soren Kaplan Schumpeter's creative destruction idea, studies were conducted showing that innovation management had a great impact on innovative organizational culture (Kaplan, 2017).

\section{Hypotheses of the Research}

$\mathbf{H}_{1 \mathbf{a}}$ : There is a significant relationship between innovation management and innovative organizational culture.

$\mathbf{H}_{1 \mathbf{b}}$ : Innovative organizational culture improves as innovation management practices increase.

$\mathbf{H}_{1 \mathbf{c}}$ : There is a significant relationship between a company's innovation performance and its innovative organizational culture.

$\mathbf{H}_{\mathbf{1 d}}$ : There is a significant relationship between a company's innovation capability and its innovative organizational culture.

$\mathbf{H}_{1 \mathbf{e}}$ : There is a significant relationship between a company's innovative organizational structure and its innovative organizational culture.

$\mathbf{H}_{1 \mathbf{f}}$ : There is a significant relationship between employees' participation in innovation processes and a company's innovative organizational culture

$\mathbf{H}_{1 \mathbf{g}}$ : There is a significant relationship between the employees' innovation desires and a company's innovative organizational culture.

$\mathbf{H}_{1 \mathbf{h}}$ : There is a significant relationship between a company's innovation support and its innovative organizational culture. 
$\mathbf{H}_{1 \mathbf{k 1}}$ : Innovative organizational culture varies by gender.

$\mathbf{H}_{\mathbf{1 k 2}}$ : Innovative organizational culture varies by marital status.

$\mathbf{H}_{1 \mathbf{k} 3}$ : Innovative organizational culture varies by age.

$\mathbf{H}_{\mathbf{1 k 4}}$ : Innovative organizational culture varies by educational status.

$\mathbf{H}_{1 \mathrm{k5}}$ : Innovative organizational culture varies by employment period.

$\mathbf{H}_{1 \mathbf{k 6}}$ : Innovative organizational culture varies by job position.

\section{Data Analysis Methods of the Research}

We analyzed the data in this study using frequency analysis, normality analysis, correlation analysis, regression analysis, independent-sample T Test, one-way ANOVA analysis, and validity and reliability analyses.

\section{Frequency Analysis}

Table 1 lists the descriptive statistics of the employees in the sample.

Table 1

Descriptive Statistics- 1

\begin{tabular}{|c|c|c|c|}
\hline & Frequency & Percentage & Cumulative Percentage \\
\hline \multicolumn{4}{|c|}{ Gender } \\
\hline Male & 113 & $56,5 \%$ & $56,5 \%$ \\
\hline Female & 87 & $43,5 \%$ & $100,0 \%$ \\
\hline \multicolumn{4}{|c|}{ Age } \\
\hline Under 20 & 2 & $1,0 \%$ & $1,0 \%$ \\
\hline $20-29$ & 59 & $29,5 \%$ & $30,5 \%$ \\
\hline $30-39$ & 103 & $51,5 \%$ & $82,0 \%$ \\
\hline $40-49$ & 29 & $14,5 \%$ & $96,5 \%$ \\
\hline 50 and above & 7 & $3,5 \%$ & $100,0 \%$ \\
\hline \multicolumn{4}{|c|}{ Educational Status } \\
\hline High School & 23 & $11,5 \%$ & $11,5 \%$ \\
\hline Undergraduate & 38 & $19,0 \%$ & $30,5 \%$ \\
\hline Graduate & 103 & $51,5 \%$ & $82,0 \%$ \\
\hline Postgraduate & 36 & $18,0 \%$ & $100,0 \%$ \\
\hline \multicolumn{4}{|c|}{ Marital Status } \\
\hline Married & 111 & $55,5 \%$ & $55,5 \%$ \\
\hline Single & 89 & $44,5 \%$ & $100,0 \%$ \\
\hline \multicolumn{4}{|c|}{ Employment Period } \\
\hline Less than 1 year & 21 & $10,5 \%$ & $10,5 \%$ \\
\hline $1-5$ years & 87 & $43,5 \%$ & $54,0 \%$ \\
\hline $6-10$ years & 59 & $29,5 \%$ & $83,5 \%$ \\
\hline $11-15$ years & 26 & $13,0 \%$ & $96,5 \%$ \\
\hline $16-20$ years & 4 & $2,0 \%$ & $98,5 \%$ \\
\hline 21 years and more & 3 & $1,5 \%$ & $100,0 \%$ \\
\hline
\end{tabular}


As Table 1 shows, $56.5 \%$ of the sample was male and $43.5 \%$ was female. Young employees aged 20-39 years comprised $81 \%$ of the sample. In addition, a significant majority of the participants, $88.5 \%$, graduated from university. There was no dominance in the distribution of marital status among the groups. Meanwhile, $43.5 \%$ of the employees in the sample had 1 to 5 years of work experience.

Table 2 shows additional descriptive statistics for the employees who participated in the study.

Table 2

Descriptive Statistics- 2

\begin{tabular}{lccc}
\hline & Frequency & Percentage & Cumulative Percentage \\
\hline TRY 1501-2000 & Monthly Salary & & \\
TRY $2001-3000$ & 42 & $21 \%$ & $21,0 \%$ \\
TRY 3001-4000 & 89 & $44,5 \%$ & $65,5 \%$ \\
TRY 4001 and above & 39 & $19,5 \%$ & $85,0 \%$ \\
\hline & 30 & $15,0 \%$ & $100,0 \%$ \\
\hline Manager & Job Position & & $6,5 \%$ \\
Domestic Logistics Operation Personnel & 13 & $6,5 \%$ & $17,5 \%$ \\
International Logistics Operation Personnel & 22 & $11,0 \%$ & $30,5 \%$ \\
Documentation Personnel & 26 & $13,0 \%$ & $39,5 \%$ \\
Officer & 18 & $9,0 \%$ & $63,0 \%$ \\
Chief & 47 & $23,5 \%$ & $77,5 \%$ \\
Domestic Sales Personnel & 29 & $14,5 \%$ & $87,0 \%$ \\
International Sales Personnel & 19 & $9,5 \%$ & $90,5 \%$ \\
Pricing Personnel & 7 & $3,5 \%$ & $94,5 \%$ \\
Other & 8 & $4,0 \%$ & $100,0 \%$ \\
\hline
\end{tabular}

As Table 2 shows, the vast majority of the employees in the sample had monthly incomes between TRY 2001 (Turkish liras) and TRY 3000. Regarding job position, the results showed that officers and chiefs were more dominant in the sample, with $23.5 \%$ and $14.5 \%$ respectively. Meanwhile, the percentages of employees in other positions were fairly close to one another.

\section{Validity and Reliability Analysis}

In order to determine the structural validity of the scales used in the study, Confirmatory Factor Analysis (CFA) was applied and the recommended fit values obtained as a result of the factor analysis for the innovation management scale consisting of 26 items are given in Table 3.

Table 3

Innovation Management Scale / Recommended Fit Values

\begin{tabular}{llllllllll}
\hline Fit Criteria & $\boldsymbol{\chi}^{\mathbf{2}}$ & $\mathbf{p}$ & $\boldsymbol{\chi}^{\mathbf{2}} / \mathbf{s d}$ & $\mathbf{R M S E A}$ & CFI & IFI & SRMR & NFI & GFI \\
\hline Recommended Fit Values & 385,312 & 0,01 & 2,335 & 0,08 & 0,857 & 0,902 & 0,05 & 0,840 & 0,900 \\
\hline
\end{tabular}


As Table 3 shows, for the recommended fit values of the innovation management scale, the chisquare value was 385.312, the p value was 0.01, the RMSEA value was 0.08 , the GFI value was 0.900 , the chisquare/degree of freedom was 2.335 , the IFI value was 0.902 , the SRMR value was 0.05 , the CFI value was 0.857 , and the NFI value 0.840 . Figure 2 shows the standardized solution values relating to the tested innovation management scale.

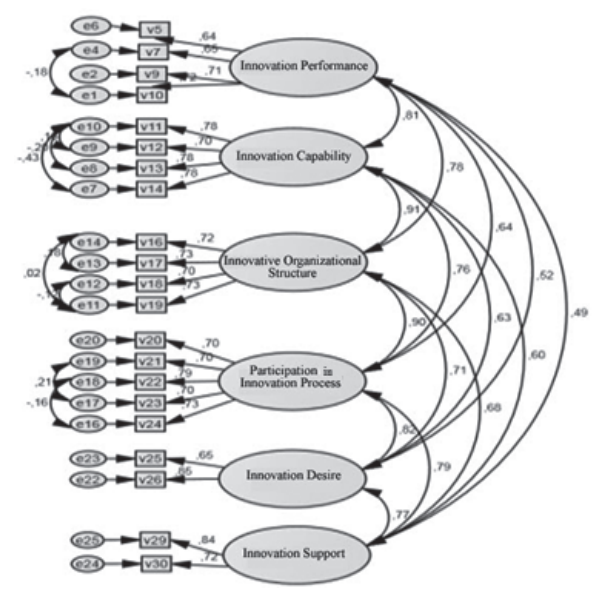

Figure 2. Innovation Management Scale / Standardized Analysis Values

Table 4 shows the recommended fit values obtained by applying Confirmatory Factor Analysis to the innovative organizational culture scale, which consisted of eight items.

Table 4

Innovative Organizational Culture Scale / Recommended Fit Values

\begin{tabular}{lcccccccccc}
\hline Fit Criteria & \multicolumn{1}{c}{$\boldsymbol{\chi}^{\mathbf{2}}$} & $\mathbf{p}$ & $\boldsymbol{\chi}^{\mathbf{2} / \mathbf{s d}}$ & $\mathbf{R M S E A}$ & CFI & IFI & SRMR & NFI & GFI \\
\hline $\begin{array}{l}\text { Recommended } \\
\text { Val u e s }\end{array}$ & Fit & 21,041 & 0,05 & 1,753 & 0,06 & 0,975 & 0,976 & 0,03 & 0,946 & 0,970 \\
\hline
\end{tabular}

As Table 4 shows, for the recommended fit values of the innovative organizational culture scale, the chi-square value was 21.041 , the $\mathrm{p}$ value was 0.05 , the RMSEA value as 0.06 , the GFI value was 0.970 , the chisquare/degree of freedom was 1.753 , the IFI value was 0.976 , the SRMR value was 0.03 , the CFI value was 0.975 , and the NFI value was 0.946 . Figure 3 shows the standardized solution values relating to the tested innovation management scale. 


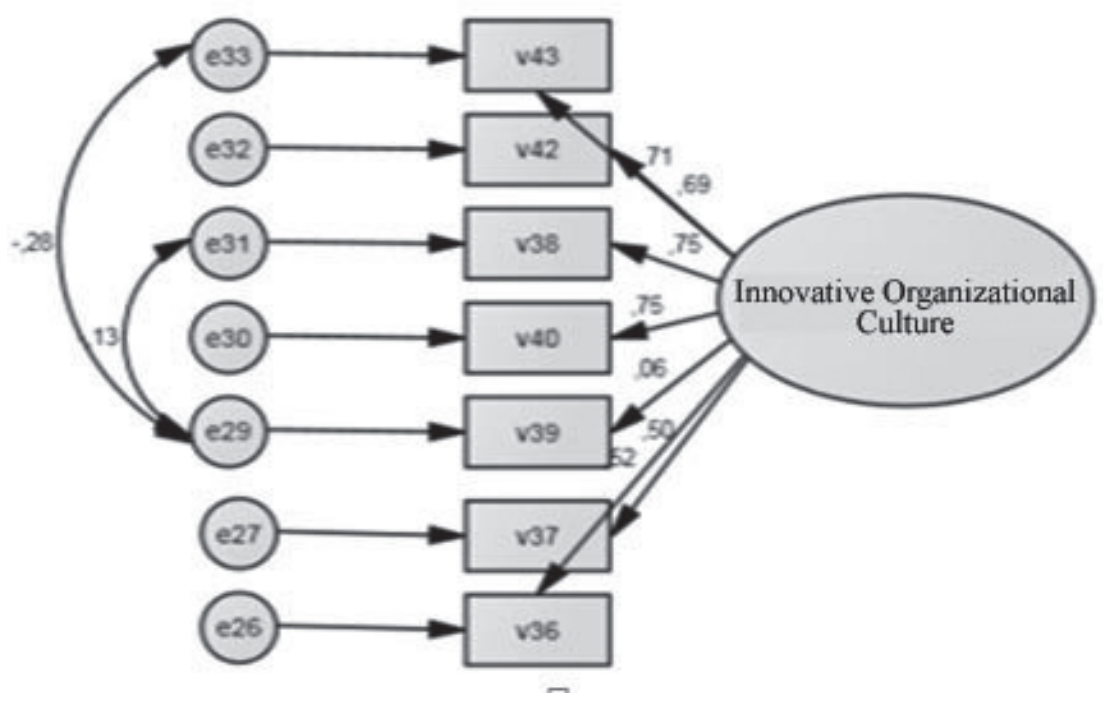

Figure 3. Innovative Organizational Culture / Standardized Analysis Values

We determined that the recommended fit values of the innovation management scale given in Table 3 and the recommended fit values of the innovative organizational culture scale given in Table 4 were in accordance with the goodness of fit statistics published by Schermelleh Engel et al. (2003) and the structural validity of the scales used in the study were therefore at an acceptable level.

After completing the Confirmatory Factor Analysis, we removed 5 items from the innovation management scale and 1 item from the innovative organizational culture scale. Table 5 shows the values obtained as a result of the reliability analysis performed for these scales whose structural validity was established.

Table 5

Reliability Analysis

\begin{tabular}{ccc}
\hline & Cronbach's Alpha & N of Items \\
\hline Innovative Organizational Culture Scale & 0.728 & 7 \\
Innovation Management Scale & 0.935 & 21 \\
* Innovation Performance & 0.763 & 4 \\
* Innovation Capability & 0.821 & 4 \\
* Innovative Organizational Structure & 0.813 & 4 \\
* Participation in Innovation Process & 0.847 & 5 \\
* Innovation Desire & 0.712 & 2 \\
* Innovation Support & 0.752 & 2 \\
\hline
\end{tabular}

As Table 5 shows, the Cronbach's Alpha coefficients were 0.728 for the innovative organizational culture scale, 0.935 for the innovation management scale, 0.763 for the innovation 
performance dimension, 0.821 for the innovation capability dimension, 0.813 for the innovative organizational structure dimension, 0.847 for the participation in the innovation process, 0.712 for the innovation desire dimension, and 0.752 for the innovation support dimension. These values verified that the scales used in this study were internally consistent.

\section{Normality Analysis}

Table 6 shows the Kolmogorov-Smirnov and Shapiro-Wilk values, derived from the normality test we conducted, and Table 7 provides the descriptive statistics. The Kolmogorov-Smirnov values in Table 6 indicate that the data obtained from all scales do not show a normal distribution.

\section{Table 6}

Normality Test Results

\begin{tabular}{lcccccc}
\hline & \multicolumn{3}{c}{ Kolmogorov-Smirnov } & \multicolumn{3}{c}{ Shapiro-Wilk } \\
\cline { 2 - 6 } & Statistic & df & Sig. & Statistic & df & Sig. \\
\hline Innovative Organizational Culture & 0.098 & 200 & 0.000 & 0.983 & 200 & 0.017 \\
Innovation Management & 0.101 & 200 & 0.000 & 0.960 & 200 & 0.000 \\
* Innovation Performance & 0.138 & 200 & 0.000 & 0.951 & 200 & 0.000 \\
* Innovation Capability & 0.101 & 200 & 0.000 & 0.960 & 200 & 0.000 \\
* Innovative Organizational Structure & 0.176 & 200 & 0.000 & 0.924 & 200 & 0.000 \\
* Participation in Innovation Process & 0.118 & 200 & 0.000 & 0.970 & 200 & 0.000 \\
* Innovation Desire & 0.136 & 200 & 0.000 & 0.953 & 200 & 0.000 \\
* Innovation Support & 0.136 & 200 & 0.000 & 0.953 & 200 & 0.000 \\
\hline
\end{tabular}

Table 7 displays the skewness and kurtosis values of the data obtained from the scales we used in this study. As the results in the table indicate, we found that the skewness and kurtosis values of the data obtained from the scales - which did not show a normal distribution based on the Kolmogorov-Smirnov value - were in the range of -2 to +2 , thus showing a normal distribution based on the classification of George and Mallery (2003). For this reason, we used parametric techniques within the scope of the research.

Table 7

Normality Tests - Descriptive Statistics

\begin{tabular}{llcc}
\hline & & Statistic & Std. Error \\
\hline \multirow{2}{*}{ Innovative Organizational Culture } & Skewness & -0.280 & 0.172 \\
& Kurtosis & 0.349 & 0.342 \\
Innovative Management & Skewness & -0.614 & 0.172 \\
* Innovation Performance & Kurtosis & 1.277 & 0.342 \\
& Skewness & -0.777 & 0.172 \\
* Innovation Capability & Kurtosis & 1.688 & 0.342 \\
* Innovative Organizational Structure & Skewness & -0.614 & 0.172 \\
* Participation in Innovation Process & Kurtosis & 1.277 & 0.342 \\
* Innovation Desire & Skewness & -0.956 & 0.172 \\
* Innovation Support & Kurtosis & -0.477 & 0.342 \\
& Skewness & 0.569 & 0.172 \\
& Kurtosis & -0.413 & 0.342 \\
& Skewness & -0.130 & 0.172 \\
\end{tabular}




\section{Correlation Analysis}

Table 8 shows the results of the correlation analysis between this study's dependent and independent variables. As the results in the table indicate, our analysis showed a highly significant positive relationship between innovation management and innovative organizational culture. In addition, we found that innovative organizational culture had moderately significant positive relationships with innovation performance, innovation desire, and innovation support - the sub-dimensions of innovation management. We also found that innovative organizational culture had highly significant positive relationships with the innovation capability, innovative organizational structure and participation in the innovation process dimension. In most of the surveyed companies, the provision of the budgets necessary for innovation, the testing of innovative ideas, and personnel initiative impacted on the emergence of these significant relationships. Moreover, managers' willingness to support employees' risk taking and efforts to improve themselves supported this positive relationship.

Table 8

Correlation Analysis

\begin{tabular}{lcc}
\hline & & Innovative Organizational Culture \\
\hline Innovation Management & Pearson Correlation & 0.831 \\
& Sig. (2-tailed) & 0.000 \\
$*$ Innovation Performance & Pearson Correlation & 0.557 \\
& Sig. (2-tailed) & 0.000 \\
$*$ Innovation Capability & Pearson Correlation & 0.632 \\
* Innovative Organizational & Sig. (2-tailed) & 0.000 \\
Structure & Pearson Correlation & 0.642 \\
$*$ Participation in Innovation & Sig. (2-tailed) & 0.000 \\
Process & Pearson Correlation & 0.603 \\
$*$ Innovation Desire & Sig. (2-tailed) & 0.000 \\
$*$ Innovation Support & Pearson Correlation & 0.561 \\
& Sig. (2-tailed) & 0.000 \\
& Pearson Correlation & 0.554 \\
\hline
\end{tabular}

\section{Regression Analysis}

Table 9 shows the ANOVA results of our multiple regression analysis of innovation management and innovative organizational culture. Our analysis indicated that the regression model was statistically significant because the F value of the model was less than 0.05 .

Table 9

Innovation Management \& Innovative Organizational Culture - ANOVA

\begin{tabular}{llcccc}
\hline & \multicolumn{2}{c}{ Sum of Squares } & Mean Square & F & Sig. \\
\cline { 2 - 5 } Innovative & Regression & 1869.044 & 311.507 & & \\
Organizational & Residual & 1526.351 & 7.909 & 39.389 & 0.000 \\
Culture & Total & 3395.395 & & & \\
\hline
\end{tabular}


Table 10 shows the results of the multiple regression analysis conducted using the backward method. As these results indicate, our analysis determined that $53.9 \%$ of the changes in the innovative organizational culture were explained by the changes in the five dimensions of innovation management. According to these results, the value of innovative organizational culture can be formulated as follows: "Innovative Organizational Culture $=5.960+(0.239 \mathrm{x}$ Innovation Performance $)+(0.292$ x Innovation Capability $)+(0.393$ x Innovation Support $)+$ (0.286 x Innovative Organizational Structure $)+(0.491$ x Innovation Desire)"

Table 10

Innovation Management \& Innovative Organizational Culture - Model

\begin{tabular}{|c|c|c|c|c|c|c|}
\hline \multirow{8}{*}{$\begin{array}{l}\text { Innovative } \\
\text { Organizational } \\
\text { Culture }\end{array}$} & Innovation Management & $\boldsymbol{\beta}$ & $\mathbf{t}$ & Sig. & $\mathbf{R}^{\mathbf{2}}$ & Adjusted R 2 \\
\hline & Constant & 5.960 & 4.446 & 0.000 & & \\
\hline & Innovation Performance & 0.239 & 2.229 & 0.027 & & \\
\hline & Innovation Capability & 0.292 & 2.360 & 0.019 & & \\
\hline & Innovation Support & 0.393 & 2.816 & 0.005 & 0.550 & 0.539 \\
\hline & Innovative Organizational Structure & 0.286 & 2.277 & 0.024 & & \\
\hline & Participation in Innovation Process & -0.005 & -0.048 & 0.962 & & \\
\hline & Innovation Desire & 0.491 & 3.141 & 0.002 & & \\
\hline
\end{tabular}

Based on the formula obtained from the regression analysis, we found that a 1-unit increase in the innovation performance dimension of innovation management led to an increase of 0.239 units in the innovative organizational culture, a 1-unit increase in the innovation capability dimension led to an increase of 0.292 units in innovative organizational culture, a 1 -unit increase in the innovation support dimension led to an increase of 0.393 units in innovative organizational culture, a 1-unit increase in the innovative organizational structure dimension led to an increase of 0.286 units in innovative organizational culture, and an increase of 1 unit in the innovation desire dimension led to an increase of 0.491 units in innovative organizational culture. When evaluated together with the other dimensions of the innovation management, we found that the participation in the innovation process dimension had no significant effect on innovative organizational culture.

\section{Independent-Sample T Test}

Table 11 shows the results of our analysis of the relationship between innovative organizational culture and the gender of the participants. As the results in this table indicate, we found a significance value greater than 0.05 , indicating that employees' perceptions of innovative organizational culture did not differ significantly based on gender. Perceptions of innovative organizational culture serve as indicators of uncertainty, the ability to tolerate reasonable mistakes, and the extent to which these errors are regarded as opportunities. In fact, the concept of innovative organizational culture is closely related to company management practices. This supports the validity of our finding of no relationship between perceptions of innovative organizational culture and gender. 
Table 11

Innovative Organizational Culture \& Gender / Independent-Samples T Test

Levene's Test for Equality of Variances t-test for Equality of Means

\begin{tabular}{lccccccc}
\hline & F & Sig. & t & df & $\begin{array}{c}\text { Sig. } \\
\text { (2-tailed) }\end{array}$ & $\begin{array}{c}\text { Mean } \\
\text { Difference }\end{array}$ & $\begin{array}{c}\text { Std. Error } \\
\text { Difference }\end{array}$ \\
\hline $\begin{array}{l}\text { Equal variances } \\
\text { assumed }\end{array}$ & 1.598 & 0.208 & 0.714 & 198 & 0.476 & 0.42142 & 0.58989 \\
$\begin{array}{l}\text { Equal variances } \\
\text { not assumed }\end{array}$ & & & 0.728 & 195.380 & 0.467 & 0.42142 & 0.57873 \\
\hline
\end{tabular}

Table 12 shows the results of our analysis of the relationship between innovative organizational culture and participants' marital status. As the results in the table indicate, we found a significance value greater than 0.05 , indicating that employees' perceptions of innovative organizational culture did not differ significantly based on marital status. Whether married or single, employees recognized that innovation practices became the organizational culture after a certain period of time.

Table 12

Innovative Organizational Culture \& Marital Status / Independent-Samples T Test

\begin{tabular}{lcccccccc}
\hline & \multicolumn{3}{c}{$\begin{array}{c}\text { Levene's Test } \\
\text { for Equality of } \\
\text { Variances }\end{array}$} & & \multicolumn{3}{c}{ t-test for Equality of Means } \\
& F & Sig. & t & df & $\begin{array}{c}\text { Sig. } \\
\text { (2-tailed) }\end{array}$ & $\begin{array}{c}\text { Mean } \\
\text { Difference }\end{array}$ & $\begin{array}{c}\text { Std. Error } \\
\text { Difference }\end{array}$ \\
\hline Equal variances assumed & 0.014 & 0.905 & -1.402 & 198 & 0.162 & -0.82205 & 0.58631 \\
Equal variances not assumed & & & -1.396 & 185.485 & 0.164 & -0.82205 & 0.58875 \\
\hline
\end{tabular}

\section{One-Way ANOVA Test}

Table 13 shows the results of our analysis of the relationship between innovative organizational culture and participants' ages.

Table 13

Innovative Organizational Culture-Age / One-Way ANOVA Analysis

\begin{tabular}{|c|c|c|c|c|c|c|c|}
\hline $\begin{array}{l}\text { Innovative } \\
\text { Organizational } \\
\text { Culture }\end{array}$ & & $\mathbf{N}$ & Mean & Std. Deviation & Std. Error & $\mathbf{F}$ & Sig. \\
\hline & Below 20 & 2 & 25.5000 & 0.70711 & 0.50000 & 1.097 & 0.359 \\
\hline & $20-29$ & 59 & 25.3051 & 3.64008 & 0.47390 & & \\
\hline & $30-39$ & 103 & 24.4660 & 3.82411 & 0.37680 & & \\
\hline & $40-49$ & 29 & 23.4483 & 5.38905 & 1.00072 & & \\
\hline & 50 and above & 7 & 23.8571 & 6.41427 & 2.42437 & & \\
\hline
\end{tabular}

As the results in Table 13 indicate, we found a significance value greater than 0.05 , meaning perceptions of innovative organizational culture did not differ significantly based on employee age. The non-heterogeneous distribution of the age of the personnel was effective in this result. 
Table 14 shows the results of our analysis of the relationship between perceptions of innovative organizational culture and participants' educational status.

Table 14

Innovative Organizational Culture - Education / One-Way ANOVA Analysis

\begin{tabular}{|c|c|c|c|c|c|c|c|}
\hline $\begin{array}{l}\text { Innovative } \\
\text { Organizational } \\
\text { Culture }\end{array}$ & & $\mathbf{N}$ & Mean & Std. Deviation & Std. Error & $\mathbf{F}$ & Sig. \\
\hline & High School & 23 & 25.7826 & 3.74113 & 0.78008 & 0.932 & 0.426 \\
\hline & Undergraduate & 38 & 23.9737 & 4.89062 & 0.79336 & & \\
\hline & Graduate & 103 & 24.5146 & 3.94537 & 0.38875 & & \\
\hline & Post Graduate & 36 & 24.5000 & 4.02492 & 0.67082 & & \\
\hline
\end{tabular}

As the results in Table 14 indicate, we found a significance value greater than 0.05 , indicating that perceptions of innovative organizational culture did not differ significantly based on an employee's education level. Because Turkey's logistics industry has recently developed, this sector is in a very good condition in terms of the qualifications of the white-collar staff it employs. The level of training of white-collar staff in this sector is nearly uniform. In other words, most of the white-collar employees in this sector have graduated from the logistics departments of high schools, universities, and postgraduate programs. This enables employees to perceive the innovation activities related to their own fields and the transformation of these innovative efforts into organizational culture at an equal level.

Table 15 shows the results of our analysis of the relationship between perceptions of innovative organizational culture and the duration of participants' employment.

Table 15

Innovative Organizational Culture-Employment Period / One-Way Analysis

\begin{tabular}{|c|c|c|c|c|c|c|c|}
\hline $\begin{array}{l}\text { Innovative } \\
\text { Organizational } \\
\text { Culture }\end{array}$ & & $\mathbf{N}$ & Mean & Std. Deviation & Std. Error & $\mathbf{F}$ & Sig. \\
\hline & Less than 1 year & 21 & 27.4286 & 3.27981 & 0.71571 & 3.925 & 0.002 \\
\hline & $1-5$ years & 87 & 24.2989 & 3.46449 & 0.37143 & & \\
\hline & $6-10$ years & 59 & 24.0678 & 4.08050 & 0.53124 & & \\
\hline & $11-15$ years & 26 & 25.0385 & 5.77221 & 1.13202 & & \\
\hline & $16-20$ years & 4 & 19.2500 & 3.30404 & 1.65202 & & \\
\hline & 21 years and more & 3 & 24.3333 & 1.52753 & 0.88192 & & \\
\hline
\end{tabular}

As the results in Table 15 indicate, we found a significance value less than 0.05 in both analyses, indicating that perceptions of innovative organizational culture differed significantly based on employment duration. More specifically, our analysis showed that perceptions of the innovative organizational culture were most positive among employees with less than 1 year of work experience and most negative among employees with work experience of 16-20 years. With the development of technology and increasing educational opportunities, youth today are more open and predisposed to innovation. Newly graduated individuals can recognize deficiencies in organizations, requisite innovations, and innovation attempts more easily 
than older personnel who have gained a certain amount of experience. In other words, young employees tend to transform innovation into innovative organizational culture. Meanwhile, most employees who have worked for 16-20 years are closed to innovation because they do not want to change certain habits, and because they do not develop themselves, they have difficulty in perceiving the innovation attempts in the organization and transforming them into organizational culture. In addition, new employees bring fresh blood to organizations and cure the various forms of blindness that result from the long-term ordinary work routines of old employees.

Table 16 shows the results of our analysis of the relationship between perceptions of innovative organizational culture and participants' job positions.

Table 16

Innovative Organizational Culture \& Job Position / One-Way ANOVA Analysis

\begin{tabular}{|c|c|c|c|c|c|c|c|}
\hline $\begin{array}{l}\text { Innovative } \\
\text { Organizational } \\
\text { Culture }\end{array}$ & & $\mathbf{N}$ & Mean & Std. Deviation & $\begin{array}{l}\text { Std. } \\
\text { Error }\end{array}$ & $\mathbf{F}$ & Sig. \\
\hline & Manager & 13 & 26.2308 & 4.16641 & 1.15555 & 1.880 & 0.057 \\
\hline & $\begin{array}{l}\text { Domestic Logistics } \\
\text { Operation Personnel }\end{array}$ & 22 & 26.6364 & 3.67158 & 0.78278 & & \\
\hline & $\begin{array}{l}\text { International Logistics } \\
\text { Operation Personnel }\end{array}$ & 26 & 25.1538 & 3.33097 & 0.65326 & & \\
\hline & Documentation Personnel & 18 & 24.0000 & 3.46410 & 0.81650 & & \\
\hline & Officer & 47 & 23.4043 & 4.31710 & 0.62971 & & \\
\hline & Chief & 29 & 23.7241 & 4.65139 & 0.86374 & & \\
\hline & Domestic Sales Personnel & 19 & 25.0000 & 4.29470 & 0.98527 & & \\
\hline & $\begin{array}{c}\text { International Sales } \\
\text { Personnel }\end{array}$ & 7 & 26.5714 & 2.14920 & 0.81232 & & \\
\hline & Pricing Personnel & 8 & 23.5000 & 3.58569 & 1.26773 & & \\
\hline & Other & 11 & 23.7273 & 4.81852 & 1.45284 & & \\
\hline
\end{tabular}

When Table 16 was examined, it was found that the significance value was greater than 0.05 , and that therefore the perception of innovative organizational culture did not show a significant difference according to the job position. To foster an innovative organizational culture in an organization, all stakeholders must work in coordination with each other. In other words, if a staff member in a job position leads an innovation activity, the innovations that member brings to the organization will be adopted and applied by employees in other positions and these innovations will spread to the whole organization and contribute to the transformation of the organizational culture after a certain period of time. Thus, the finding that perceptions of the innovative organizational culture did not differ significantly based on job positions appears quite apt, since transforming innovations into an organizational culture depends on equal perceptions and internalization of the applied innovations by the employees in each position. 


\section{Discussion and Conclusions}

Today, trade has become globalized in the fullest sense and the world has become almost a single market. In this environment, logistics companies must compete both with companies in their own regions and with companies from all around the world. This competition among logistics companies manifests in decreased sales prices resulting from increased customer demands, increased costs, and increased competition levels, all of which ultimately shrink profit margins. The only way logistics companies can tackle such difficulties and take the lead in competition in a sustainable manner is by implementing management approaches that internalize innovation and adopt it as a core principle. At the same time, logistics companies should keep up with scientific and technological innovations and adopt service differentiation throughout all their departments to provide inexpensive and high quality services to customers. In the face of these inevitable developments, company managers must replace traditional management strategies with modern approaches. Innovation and innovation management should be the main source for all logistics companies operating in national and international fields, because innovation feeds globalization and globalization feeds logistics. In short, ensuring that these three phenomena feed each other requires innovation. Innovation also feeds many logistics operations such as warehousing, transportation, inventory management, order management, accounting/financing, and information processing, and it increases the profitability and efficiency of logistics companies. The fact that innovation generates positive results for logistics companies highlights the importance of this study's investigation of this subject and related concepts.

From this point of view, it can be said that it is necessary or even obligatory to implement innovation management in an organization and to build an innovative organizational culture. The results of the study also support this. As a result of the study, it has been concluded that there is a relationship between innovation management practices and innovative organizational culture and that innovation management practices improve the innovative organizational culture. Values of innovation performance $(b=0.239)$, innovation capacity $(b=0.292)$, innovation support $(b=0.393)$, innovative organizational structure $(b=0.286)$ and desire for innovation $(b=0.491)$, being among sub-dimensions of innovative management, are concrete indicators of this situation. These concrete results from the study show that innovation management and its sub-dimensions are effective in transforming the existing organizational culture into an innovative organizational culture. Current studies on this subject in the literature also support this result. One of the studies available in the literature, with similar results, is the study conducted by Ceausu et al., (2017). In this study, Ceausu et al. (2017) pointed out that the focus of managers on innovation management encourages innovation throughout the organization and this is an effective factor in the formation of an innovative organizational culture (Ceausu et al., 2017: 2398). Davies and Buisine (2018) stated that the existing organizational culture could be transformed into an innovative organizational culture 
by ensuring that potential innovation resources are increased within the organization through innovation management (Davies and Buisine, 2018: 102). Martins and Terblanche (2003) emphasized that behaviors that encourage innovation should be nurtured in order to create an organizational culture that stimulates innovation and creativity in an organization (Martins and Terblanche, 2003: 73).

This research in the logistics industry guides decision makers on how innovation management practices can be transformed into an organization's culture. In other words, the results obtained from this research give decision makers an idea of what steps can be taken to transform innovation into organizational culture. Innovation management practices recommended for decision makers for each sub-dimension of innovation management affecting the innovative organizational culture were determined as follows in this research. For the innovation performance sub-dimension, it is recommended to managers that they share information within the organization and thereby increase their innovation performance (Işık and Aydın, 2016: 86). Within the scope of sub-dimension of innovation capability, decision makers are advised to implement the talent management successfully. Because employing, training, and developing talented employees, keeping them in the company, providing career opportunities and operating a reward system contribute positively to the improvement of innovation performance. (Şahin and Özdoğan, 2015: 387). Within the scope of innovation support, the enterprise must be involved in activities such as supporting and developing new ideas, welcoming employees to take risks positively and pleasantly, supporting new projects with a high chance of failure. As can be seen, the support of top management is an undeniable fact in the employee's innovative behavior. Top managers working in this sector must support innovation management practices and develop their skills in this direction (Pelenk, 2017: 5). Within the scope of the innovative organizational structure, in order to establish an organizational structure where creativity is directed and supported, organization employees must be guided and supported in creativity dimension. What is meant by giving directions and providing support is reducing formalization and specialization as much as possible or innovation-oriented, facilitating the initiative of employees by avoiding hierarchy, strengthening the relationships and interaction between organizational sub-systems, and strengthening employees with more decentralization (participant management). Therefore, in terms of contextual elements, it is necessary to include creativity and innovation as a value in organizational culture, to set up an R\&D unit or innovation team, to run them effectively and to build simple and flexible structures (Özdaşl1, 2010: 109). Within the scope of dimension of innovation desire, employees who desire to develop their work must be granted individual autonomy within the organization. Individual autonomy within the company will contribute to employees' efforts to improve their work, to generate new ideas and to successfully implement these ideas (Eren and Kılıç, 2013: 226). In addition to these dimensions mentioned, it was determined in this study that the working time of the employees was also effective on the innovative organizational culture. 
It is considered that sharing the results of this study with the managers in the logistics industry would contribute to the development of professional management and innovative leaders. This study also has significant value in terms of the fact that it shows the managers that innovative organizational culture, being an outcome of innovative management and innovative management practices, is a beneficial tool that can be used in managing a company, because one of the tools that provide useful outcomes for the enterprise is innovation management practices. In addition, the fact that there are very few studies in the literature that examined the relationship between these two concepts and that this subject has never been applied in the logistics sector until today, it is another contribution to the sector provided by this study.

Overall, our findings suggest that innovation and innovation awareness should be instilled in business owners, managers, and all other personnel. Innovation management should be implemented in all departments to cover all areas of business in logistics companies as well as companies operating in other sectors and organizations should seek to transform innovation management into an organizational culture. Today, due to the increasing number of logistics companies and the continuous development of technology with each passing day, managers need to closely follow developments and integrate what they see and learn into their companies.

Within the scope of the research, the results of the hypothesis tests performed to determine whether the difference between the two groups or the change over time is random are detailed in Table 17.

Table 17

Test Matrix of Research Hypotheses

\begin{tabular}{cccccc}
\hline Hypothesis & Result & Sig. & Hypothesis & Result & Sig. \\
\hline $\mathrm{H}_{1 \mathrm{a}}$ & Accepted & 0.000 & $\mathrm{H}_{1 \mathrm{~h}}$ & Accepted & 0.000 \\
$\mathrm{H}_{1 \mathrm{~b}}$ & Accepted & 0.000 & $\mathrm{H}_{1 \mathrm{k} 1}$ & Rejected & 0.476 \\
$\mathrm{H}_{1 \mathrm{c}}$ & Accepted & 0.000 & $\mathrm{H}_{1 \mathrm{k} 2}$ & Rejected & 0.162 \\
$\mathrm{H}_{1 \mathrm{~d}}$ & Accepted & 0.000 & $\mathrm{H}_{1 \mathrm{k} 3}$ & Rejected & 0.359 \\
$\mathrm{H}_{1 \mathrm{e}}$ & Accepted & 0.000 & $\mathrm{H}_{1 \mathrm{k} 4}$ & Rejected & 0.426 \\
$\mathrm{H}_{1 \mathrm{f}}$ & Accepted & 0.000 & $\mathrm{H}_{1 \mathrm{k} 5}$ & Accepted & 0.002 \\
$\mathrm{H}_{1 \mathrm{~g}}$ & Accepted & 0.000 & $\mathrm{H}_{1 \mathrm{k} 6}$ & Rejected & 0.057 \\
\hline
\end{tabular}

It is recommended that this study, which examines the relationship between innovative management practices and innovative organizational culture, be conducted especially in other sectors with higher rates of change and innovation, on a larger sample scale and on people working in management positions. Having reached in the study only the logistics companies which operate in the city of Mersin and which apply innovative management, and the presence of companies, among the ones reached, who did not want to contribute to the research constitute the limitation of the research. 
Peer-review: Externally peer-reviewed.

Conflict of Interest: The authors have no conflict of interest to declare.

Grant Support: The authors declared that this study has received no financial support.

\section{References}

Asmawi, A., \& Mohan, A. V. (2011). Unveiling dimensions of organizational culture: An exploratory study in Malaysian R\&D organizations. R\&D Management, 41(5), 509-523.

Bagno, R. B., Salerno, M. S., \& Silva, D. O. (2017). Models with graphical representation for innovation management: A literature review. $R \& D$ Management, 47(4), 637-653.

Bayhan, B. Ç., \& Korkmaz, O. (2018). Lojistik işletmelerinde yenilik yönetimi ile yenilikçi örgüt kültürü ilişskisi (Master's thesis, Mersin University, Turkey). Retrieved from https://tez.yok.gov.tr/UlusalTezMerkezi/tezSorguSonucYeni.jsp

Ceausu, I., Murswieck, R., Kurth, L. B., \& Ionescu, R. (2017). The organizational culture as a support of innovation processes. International Journal of Advanced Engineering and Management Research, 2(6), 2392-2403.

Chong, X., \& Chun-sheng, S. (2007, August). The impact of culture- oriented organizational innovation on technological innovation. Jiuping Xu (Chair), 2007 international conference on management science \& engineering. Symposium conducted at the meeting of the Harbin Institute of Technology, Harbin, China.

Davies, M., \& Buisine, S. (2018). Science, technology and innovation culture. Marianne Chouteau, Joëlle Forest \& Céline Nguyen (Eds.), Innovation culture in organizations (pp. 101-112). London, UK: Wiley Online Library.

Dombrowski, C., Kim, Y. J., Desouza, C. K, Braganza, A., Papagari, S., Baloh, P., \& Jha, S. (2007). Elements of innovative cultures, Knowledge and Process Management, 14(3), 190-202. https://doi.org/10.1002/ $\operatorname{kpm} .279$

Eren, H., \& Kılıç, A. (2013). Innovative environment in organizations: Especially the situation in defense industry as a sector. Atatürk University Economics and Administrative Sciences Journal, 27(3), 221-244.

Etges, A. P. B. S., \& Cortimiglia, M. N. (2019). A systematic review of risk management in innovation-oriented firms. Journal of Risk Research, 22(3), 364-381. https://doi.org/10.1080/13669877.2017.1382558

George, D., and Mallery, P. (2003). SPSS for windows step by step: A simple guide and reference. Boston, MA: Allyn \& Bacon.

Gürsel, Ü., \& Sü Eröz, S. (2017). Relationship of organizational dependency and innovative management: A research on kitchen personnel (Master's thesis, Mersin University, Turkey). Retrieved from https://tez. yok.gov.tr/UlusalTezMerkezi/tezSorgu SonucYeni.jsp

Haleem, A., Kumar, S., \& Luthra, S. (2018). Flexible system approach for understanding requisites of product innovation management. Global Journal of Flexible Systems Management, 19(1), 19-37.

Hirte, R., \& Roth, P. (2018). Advanced innovation management: Best practice of German and American corporations in the mobility sector. Journal of Strategic Innovation and Sustainability, 13(5), 111-126. https://doi.org/10.23919/PICMET.2018.8481904

Hörlesberger, M., El-Nawawi, M., \& Khalil, T. (2007). Challenges in the management of new Technologies. Miami, FL: World Scientific 
Işık, C., \& Aydın, E. (2016). Effect of information sharing on innovative work behaviors: An application on accommodation enterprises in the plateau of Ayder. Entrepreneurship and innovation management journal, 5(2), 75-103.

Kalivas, Y., Gkofa, F., Rakovitis, C., Tonkov, A., Petrov, V., \& Borut, L. (2013). Innovation management. Borut Likar (Eds.), Basic on innovation (pp. 13-25). Ljubljana, Slovenia: Korona plus d.o.o., Institute for Innovation and Technology.

Kaplan, Soren (2017). The invisible advantage: How to create a culture of innovation. Austin, TX: Greenleaf Book Group.

Maher, L. (2014). Building a culture for innovation: A leadership challenge. World Hospitals and Health Services, 50(1): 4-6.

Martins, E.C., \& Terblanche,F.(2003). Building organisational culture that stimulates creativity and innovation. European Journal of Innovation Management, 6(1), 64-74. https://doi.org/10.1108/14601060310456337

MIP (2018). Mersin international port panorama. Retrieved from https://www.mersinport.com.tr/images/pdf/ MIP_Panorama_2018_4Q.pdf

Morente, F., \& Ferràs, X. (2017). Innovation management from the inside: An approach from attention and everyday praxis. Intangible Capital, 13(3), 640-667. https://doi.org/10.3926/ic.1004

Owoyemi, O. O., \& Ekwoaba, J. O. (2014). Organisational culture: A tool for management to control, motivate and enhance employees' performance. American Journal of Business and Management, 3(3), 168177. https://doi.org/10.11634/216796061403514

Özdaşl1, K. (2010). Establishing innovative organizational structure in enterprises: Proposal of a multi-factor model. TSA, 14(1), 93-110.

Pelenk, S. E. (2017). Impact of individual innovative behaviors on individual business performance: A research on technology employees. Journal of Emerging Economies and Policy, 2(2), 2-14.

Plessis, M. J. D., \& Pretorius, M. W. (2018, August). Does my organization need an innovation management function? : Towards a model for evaluation. Dundar F. Kocaoglu (Chair), PICMET'18 conference. Symposium conducted at the meeting of the Portland International Center for Management of Engineering and Technology, Hawaii, USA.

Schermelleh-Engel, K., Moosbrugger, H., \& Müller, H. (2003). Evaluating the fit of structural equation models: Tests of significance and descriptive goodness-of-fit measures. Methods of Psychological Research Online, 8(2), 23-74.

Szczepańska-Woszczyna, K. (2014). The importance of organizational culture for innovation in the company. Forum Scientiae Oeconomia, 2(3), 27-39.

Şahin, Ö., \& Özdoğan, O. N. (2015, May). Relationship between skills management and innovative performance: The Bodrum example. Hakkı Gökbel, Muammer Erol (Chair), I. Eurasia international tourism congress: Current issues, trends and indicators (EITOC) / I. Eurasia international tourism congress: Current issues, trends and indicators (EITOC). Symposium conducted at the meeting of the Selçuk Üniversitesi Turizm Fakültesi, Konya, Turkey

Taghizadeh, S. K., Jayaraman, K., Rahman, S. A., \& Quazi, A. (2017). Service innovation management practices and pricing practices for performance in Malaysian telecom. Asian Academy of Management Journal, 22(2), 129-155. https://doi.org/10.21315/aamj2017.22.2.5

Ülgen, H., \& Mirze, S. K. (2014). İşletmelerde stratejik yönetim. İstanbul, Turkey: Beta Basım Yayım Dağıtım A.Ş.

Wallach, E. J. (1983). Individuals and organizations: The cultural match. Training and Development Journal, 37(2), 28-36.

Yi, W., \& Xiangyun, X. (2013). Obstacles to innovation management in SMEs: A case study of Libo Airport (Master's thesis, University of Gavle, Sweden). Retrieved from https://www.diva-portal.org/smash/get/ diva2:619947/FULLTEXT01.pdf 
